\title{
Protein kinase $C \delta$ expression in breast cancer as measured by real-time PCR, western blotting and ELISA
}

\author{
E McKiernan 1,2,7, K O'Brien ${ }^{1,2,7}$, N Grebenchtchikov ${ }^{3,7}$, A Geurts-Moespot ${ }^{3}$, AM Sieuwerts ${ }^{4}$, JWM Martens ${ }^{4}$, \\ V Magdolen ${ }^{5}$, D Evoy ${ }^{2}$, E McDermott ${ }^{2}$, J Crown ${ }^{6}$, FCGJ Sweep ${ }^{3}$ and MJ Duffy ${ }^{*, 1,2}$ \\ 'Department of Pathology and Laboratory Medicine, St Vincent's University Hospital, Dublin, Ireland; '2UCD School of Medicine and Medical Science, \\ Conway Institute of Biomolecular and Biomedical Research, University College Dublin, Dublin, Ireland; ${ }^{3}$ Department of Chemical Endocrinology, Radboud \\ University Nijmegen Medical Centre, Nijmegen, The Netherlands; ${ }^{4}$ Department of Medical Oncology, Erasmus MC, Rotterdam, The Netherlands; \\ ${ }^{5}$ Frauenklinik der Technischen Universitaet München, Klinikum rechts der Isar, Munich, Germany; ${ }^{6}$ Department of Medical Oncology, St Vincent's \\ University Hospital, Dublin, Ireland
}

The protein kinase C (PKC) family of genes encode serine/threonine kinases that regulate proliferation, apoptosis, cell survival and migration. Multiple isoforms of PKC have been described, one of which is PKC $\delta$. Currently, it is unclear whether PKC $\delta$ is involved in promoting or inhibiting cancer formation/progression. The aim of this study was therefore to investigate the expression of PKC $\delta$ in human breast cancer and relate its levels to multiple parameters of tumour progression. Protein kinase $C \delta$ expression at the mRNA level was measured using real-time PCR $(n=208)$ and at protein level by both immunoblotting $(n=94)$ and ELISA $(n=98)$. Following immunoblotting, two proteins were identified, migrating with molecular masses of 78 and $160 \mathrm{kDa}$. The $78 \mathrm{kDa}$ protein is likely to be the mature form of PKC $\delta$ but the identity of the $160 \mathrm{kDa}$ form is unknown. Levels of both these proteins correlated weakly but significantly with PKC $\delta$ concentrations determined by ELISA (for the $78 \mathrm{kDa}$ form, $r=0.444, P<0.005, n=9 \mathrm{I}$ and for the $160 \mathrm{kDa}$ form, $r=0.237, P=0.023, n=9 \mathrm{I}$ ) and with PKC $\delta$ mRNA levels (for the $78 \mathrm{kDa}$ form, $r=0.35 \mathrm{I}, P=0.00 \mathrm{I}, n=94$ and for the $160 \mathrm{kDa}$ form, $r=0.216, P=0.037, n=94$ ). Protein kinase $C \delta$ mRNA expression was significantly higher in oestrogen receptor (ER)-positive compared with ER-negative tumours ( $P=0.007$, Mann-Whitney $U$-test). Increasing concentrations of PKC $\delta$ mRNA were associated with reduced overall patient survival $(P=0.004)$. Our results are consistent with a role for PKC $\delta$ in breast cancer progression.

British Journal of Cancer (2008) 99, I644- |650. doi: I0.I038/sj.bjc.6604728 www.bjcancer.com

Published online 28 October 2008

(c) 2008 Cancer Research UK

Keywords: breast cancer; protein kinase $\mathrm{C} \delta$

The protein kinase $\mathrm{C}$ (PKC) family of genes encode serine/ threonine kinases that regulate proliferation, apoptosis, cell survival and migration (for review, see Jackson and Foster, 2004; Griner and Kazanietz, 2007). Currently, nine PKC genes are known to exist. The PKC isoforms are classified into three subfamilies based on their structural and enzymatic properties: classical PKCs $(\alpha, \beta 1, \beta 2$ and $\gamma)$ are activated by diacylglycerol (DAG) and calcium, novel PKCs $(\delta, \varepsilon, \eta$ and $\theta)$ are activated by DAG but are calcium-insensitive and atypical PKCs $(\zeta$ and $\lambda / l)$ respond to neither DAG nor calcium. Although, originally, PKCs were believed to be mostly promitotic (Griner and Kazanietz, 2007), more recent findings suggest that the effects of at least some PKCs may be isoenzyme and cell-type dependent (Jackson and Foster, 2004; Griner and Kazanietz, 2007).

*Correspondence: Professor MJ Duffy, Nuclear Medicine Laboratory, St Vincent's University Hospital, Elm Park, Dublin 4, Ireland;

E-mail: Michael.J.Duffy@ucd.ie

7 These authors contributed equally to this work.

Received 27 February 2008; revised 17 September 2008; accepted 22 September 2008; published online 28 October 2008
One of the PKCs shown to exhibit enigmatic properties is $\mathrm{PKC} \delta$ (Jackson and Foster, 2004). Depending on the model system investigated, $\mathrm{PKC} \delta$ has been shown to act as either a positive or a negative regulator of tumour progression (Jackson and Foster, 2004). In most situations, however, $\mathrm{PKC} \delta$ has been shown to be growth inhibitory or proapoptotic (Griner and Kazanietz, 2007). In these situations, $\mathrm{PKC} \delta$ might be regarded as a tumour suppressor gene.

In one of the first studies on breast cancer, Kiley et al (1999) showed that $\mathrm{PKC} \delta$ was involved in metastasis in a rat model. More recently, Martens et al (2005) reported that hypermethylation of the PKC $\delta$ gene in oestrogen receptor (ER)-positive breast cancer patients was associated with a favourable response to hormone therapy in patients with advanced breast cancer, whereas Assender et al (2007) found that elevated $\mathrm{PKC} \delta$ protein was associated with endocrine sensitivity. In breast cell lines, on the other hand, tamoxifen-resistant subclones tend to have higher $\mathrm{PKC} \delta$ protein expression than their parental tamoxifen-sensitive counterparts (Nabha et al, 2005; Assender et al, 2007).

The aim of this study was to carry out a more detailed study on $\mathrm{PKC} \delta$ in human breast cancer, in particular to relate $\mathrm{PKC} \delta$ expression to multiple parameters of tumour progression. Our results show that increased $\mathrm{PKC} \delta$ expression is associated with 
poor outcome. This finding is consistent with a role for $\mathrm{PKC} \delta$ in breast cancer progression.

\section{MATERIALS AND METHODS}

\section{Selection of patients and patient treatment}

The breast cancers investigated in this study were random samples submitted for routine histopathology at St Vincent's University Hospital, Dublin. The piece of tumour used for experimental purposes was dissected out by a histopathologist, snap-frozen in liquid nitrogen and stored at $-80^{\circ} \mathrm{C}$ until use. Tissue samples were homogenised using a Mikro-Dismembrator (Braun Biotech T1 International, Melsungen, Germany). Table 1 summarises the characteristics of the breast carcinomas analysed. Samples were obtained with institutional board approval from St Vincent's University Hospital.

For relating $\mathrm{PKC} \delta$ to patient outcome, both disease-free and overall survival were used as end points. Disease-free interval was defined as the time from date of initial diagnosis to the date of first recurrence/metastasis. Overall survival was defined as the time from initial diagnosis to death from any cause or date of last follow-up. The median patient follow-up period was 34.8 months $(0-137)$. Thirty-nine patients $(18.8 \%)$ received adjuvant polychemotherapy, $50(24 \%)$ received monohormone therapy and 107 (51.4) received combined chemotherapy and hormonal therapy. Two patients were not given any adjuvant systemic therapy, whereas for 10 patients, the adjuvant treatment was unknown.

Table I Pathological features and ER status of the breast carcinomas used

\begin{tabular}{|c|c|c|c|}
\hline $\begin{array}{l}\text { Tumour } \\
\text { characteristics }\end{array}$ & $\begin{array}{l}\text { PCR } \\
\text { n (\%) }\end{array}$ & $\begin{array}{c}\text { Western blot } \\
n(\%)\end{array}$ & $\begin{array}{l}\text { ELISA } \\
n(\%)\end{array}$ \\
\hline \multicolumn{4}{|l|}{ Size $(\mathrm{cm})$} \\
\hline$\leqslant 2$ & $53(25.5)$ & $20(21.3)$ & $20(20.4)$ \\
\hline$>2-5$ & $127(61.1)$ & $62(66.0)$ & $62(63.2)$ \\
\hline$>5$ & $15(7.2)$ & $8(8.5)$ & $8(8.2)$ \\
\hline Unknown & $13(6.2)$ & $4(4.2)$ & $8(8.2)$ \\
\hline \multicolumn{4}{|l|}{ Grade } \\
\hline 1 and 2 & $98(47.1)$ & $38(40.4)$ & $38(38.8)$ \\
\hline 3 & $100(48.1)$ & $54(57.5)$ & $57(58.2)$ \\
\hline Unknown & $10(4.8)$ & $2(2.1)$ & $3(3.0)$ \\
\hline \multicolumn{4}{|l|}{ Nodal status } \\
\hline Negative & $87(41.8)$ & $43(45.7)$ & $4 \mid(4 \mid .8)$ \\
\hline Positive & $109(52.4)$ & $48(51.1)$ & $53(54.1)$ \\
\hline Unknown & $12(5.8)$ & $3(3.2)$ & $4(4.1)$ \\
\hline \multicolumn{4}{|l|}{$E R$} \\
\hline Negative & $51(24.5)$ & $24(25.5)$ & $24(24.5)$ \\
\hline Positive & I5I (72.6) & $69(73.4)$ & 73 (74.5) \\
\hline Unknown & $6(2.9)$ & I (I.I) & I (1.0) \\
\hline \multicolumn{4}{|l|}{ Age } \\
\hline$\leqslant 50$ & $65(31.2)$ & $24(25.5)$ & $28(28.6)$ \\
\hline$>50$ & $143(68.8)$ & $70(74.5)$ & $70(71.4)$ \\
\hline \multicolumn{4}{|l|}{ Histological type } \\
\hline Ductal & 173 (83.2) & $83(88.3)$ & $86(87.8)$ \\
\hline Lobular & $19(9.1)$ & $6(6.4)$ & $7(7.1)$ \\
\hline Ductal and lobular & I| (5.3) & $3(3.2)$ & $3(3.1)$ \\
\hline Unknown & $5(2.4)$ & $2(2.1)$ & $2(2.0)$ \\
\hline
\end{tabular}

$E R=$ oestrogen receptor.

\section{RNA isolation and real-time PCR}

RNA was extracted from tumour samples using a commercially available column-based method (RNeasy ${ }^{\mathbb{B}}$ Mini kit; Qiagen, Hilden, Germany) and cDNA synthesised using Superscript II (Invitrogen, Carlsbad, CA, USA). The quality and quantity of the RNA was assessed using gel electrophoresis and spectrophotometery. RNA was DNase I treated (DNase I; NEB, Ipswich, MA, USA) before reverse transcription and CDNA was subsequently treated with RNAse H (NEB).

The expression of three housekeeping genes, that is, porphobilinogen deaminase (PBGD), hypoxanthine-guanine phosphoribosyltransferase (HPRT) and $\beta$-actin as well as $\mathrm{PKC} \delta$ was measured using SYBR green-based real-time PCR (Roche LightCycler 2.0; Roche Diagnostics GmbH, Mannheim, Germany). The primer sequences for $\mathrm{PKC} \delta$ were sense, TTCGGGAAGGTGCTGCTTG and antisense, TGCCCTTGCTGTGTAGAAAC, whereas those for $\beta$-actin were sense, GCACAGAGCCTCGCCTTTG and antisense CGCCCACATAGGAATCCTTC. The primer sequences for PBGD and HPRT were as previously described by Sieuwerts et al (2005). Each reaction mixture contained $20 \mathrm{ng}$ of cDNA and a concentration of $0.33 \mu \mathrm{M}$ of each primer in a final volume of $20 \mu \mathrm{l}$ with Quantitect ${ }^{\mathbb{R}}$ SYBR green reaction master mix (Qiagen and Roche Diagnostics $\mathrm{GmbH}$ ). The optimised amplification protocol consisted of an initial denaturation step of $95^{\circ} \mathrm{C}$ for $15 \mathrm{~min}$, followed by 40 amplification cycles at $95^{\circ} \mathrm{C}$ for $15 \mathrm{~s}$, annealing at $60^{\circ} \mathrm{C}$ for $30 \mathrm{~s}$ and elongation at $72^{\circ} \mathrm{C}$ for $25 \mathrm{~s}$. A constant temperature ramp of $20^{\circ} \mathrm{C} \mathrm{s}^{-1}$ was used throughout each of the steps. Measurements of fluorescence were taken at the end of each cycle. The PCR products were melted by increasing the temperature from 60 to $95^{\circ} \mathrm{C}\left(0.1^{\circ} \mathrm{C} \mathrm{s}^{-1}\right)$. Finally, the samples and carousel were cooled to $40^{\circ} \mathrm{C}$. Positive and negative controls were included in each run. The negative control lacked template, whereas the positive control was pooled RNA extracted from HeLa cells. Levels of the $\mathrm{PKC} \delta$ gene, expressed relative to the housekeeping set (HPRT, $P B G D$ and $\beta$-actin), were quantified as follows: mRNA target $=E^{\left(\text {mean } C_{\mathrm{t}} \text { housekeeping-mean } C_{\mathrm{t}} \text { target }\right)}$ (Sieuwerts et al, 2005).

\section{Immunisation}

For $\mathrm{PKC} \delta$, two different 16-mer peptides (peptide PKCD2 (296-311) and peptide PKCD3 (314-329)), both located in the flexible linker region between the $\mathrm{N}$-terminal regulatory and the C-terminal protein kinase domain, were synthesised (Pineda, Berlin, Germany), conjugated to $\mathrm{KLH}$, and used for immunisations in chicken and rabbit. Immunisations were performed according to a time schedule with boosting intervals of 2 weeks. Chickens were immunised intramuscularly (pectoral muscle) with $120 \mu \mathrm{g}$ of conjugated peptide PKCD2. Eggs from the immunised chickens were collected daily and stored at $4{ }^{\circ} \mathrm{C}$.

Antibodies were isolated from egg yolk using a standard procedure of step precipitation of proteins by applying increasing concentrations of polyethyleneglycol (PEG precipitation) as described earlier (Grebenchtchikov et al, 2002). This procedure yielded IgY fractions (avian analogue of IgG) with a protein purity of approximately 95\% (SDS - PAGE). The first injection (Freund's complete adjuvant) (PKCD3) in rabbit was in the popliteal gland, whereas booster injections (Freund's incomplete adjuvant) were administered subcutaneously with 2 weeks interval. In total, 10 booster injections were administered. Blood from rabbits was collected just before the inoculations in citrate tubes. After centrifugation, the citrate plasmas were stored at $-20^{\circ} \mathrm{C}$.

For immunoblotting, unpurified rabbit anti-PKCD3 polyclonal antibodies (V35) were used, whereas for ELISA chicken, antiPKCD2 and rabbit anti-PKCD3 antibodies were affinity purified (Grebenschikov et al, 1997). Polyclonal antibodies were eluted from the columns with $\mathrm{Gly} / \mathrm{HCl}$ buffer ( $\mathrm{pH} 2.40)$, followed by immediate neutralisation to $\mathrm{pH}$ 7.5. Purified antibodies were 
characterised using 'one-side ELISA' methodology in which peptide fragments were coupled to the microtitre well. Specificity of the antibodies was verified by western blot analysis, which demonstrated a strong reaction with recombinant full-length $\mathrm{PKC} \delta$ and truncated $\mathrm{PKC} \delta$, encompassing the $\mathrm{N}$-terminal regulatory domain, but no reaction with the closely related recombinant $\mathrm{PKC} \gamma$.

\section{Protein isolation and immunoblot analysis}

Protein was extracted from tissue samples using $50 \mathrm{mmoll}^{-1}$ Tris- $\mathrm{HCl}$ (pH 7.4) containing protease inhibitor cocktail (Roche Diagnostics $\mathrm{GmbH}$ ) and Triton X-100 (1\%) under agitation at $4{ }^{\circ} \mathrm{C}$ for $1 \mathrm{~h}$. A bicinchoninic acid assay (Pierce, Rockford, IL, USA) was used to determine total protein concentration. Equal amounts of protein were separated on SDS-PAGE and transferred to nitrocellulose membranes (Sigma, St Louis, MO, USA). Membranes were blocked in 5\% low-fat dry milk (Marvel instant-dried skimmed milk) in TBS-T for $1 \mathrm{~h}$ at room temperature and then stained overnight with mouse anti-PKC $\delta$ monoclonal antibody $\left(0.25 \mu \mathrm{g} \mathrm{ml}^{-1}\right.$; BD Biosciences Pharmingen, San Diego, CA, USA (catalogue no. 610397)). Following three washes for $10 \mathrm{~min}$ in TBS-T, the membrane was incubated with $1: 1000$ horseradish peroxidase-conjugated anti-mouse secondary antibody (Sigma) for $1 \mathrm{~h}$ at room temperature before incubation with $6 \mathrm{ml}$ of chemiluminescence reagent (Luminol; Santa Cruz Biotechnology, Santa Q7 Cruz, CA, USA) for $1 \mathrm{~min}$. Membranes were exposed to $\mathrm{X}$-ray film (Fujifilm) in the dark for $15 \mathrm{~min}$. Positivity of expression was determined based on the presence of a visible band. The intensity of the protein bands observed was semiquantified using the UVIBandMap programme (Windows application VIO.02), with normalisation of $\mathrm{PKC} \delta$ protein against $\beta$-actin. Specificity of the antibody reaction was confirmed by (a) detection of the human recombinant $\mathrm{PKC} \delta$ protein (Abcam, Cambridge, UK) at $78 \mathrm{kDa}$, which was used as a positive control, (b) omission of the primary antibody and (c) detection of a similar pattern of expression using a second primary antibody against $\mathrm{PKC} \delta$ (see above for preparation of this antibody).

\section{ELISA}

Protein kinase $\mathrm{C} \delta$ concentrations were measured by ELISA with the same experimental setup as described earlier (Grebenschikov et al, 1997). The assay format incorporated four different antibodies: (a) duck anti-chicken IgY antibody, (b) chicken antiPKCD2 antibody, (c) rabbit anti-PKCD3 and (d) goat anti-rabbit antibody labelled with HRP. The procedure started by treating the microtitre plates with coating antibody (duck anti-chicken IgY, overnight at $\left.4{ }^{\circ} \mathrm{C}\right)$, followed by blocking with BSA $\left(2 \mathrm{~h}\right.$ at $\left.37^{\circ} \mathrm{C}\right)$ and incubation with capture antibody (chicken anti-PKCD2) for $2 \mathrm{~h}$ at $37^{\circ} \mathrm{C}$. Incubation with the cancer extracts, reference sample and the standards was overnight at $4^{\circ} \mathrm{C}$. For calibration, recombinant
$\mathrm{PKC} \delta$ preparation provided by Cell Sciences (Canton, MA, USA) was used. Incubation with trapping antibody (rabbit anti-PKCD3) as well as the subsequent incubation with detection antibody (goat anti-rabbit labelled with HRP) was performed for $2 \mathrm{~h}$ at ambient temperature. The incubation with OPD substrate solution was performed in darkness for $30 \mathrm{~min}$ at ambient temperature. The reaction was stopped by the addition of $\mathrm{H}_{2} \mathrm{SO}_{4}$ and the optical density was measured at $492 \mathrm{~nm}$ within $30 \mathrm{~min}$. The analytical sensitivity, defined as the amount of $\mathrm{PKC} \delta$ giving a signal in the ELISA greater than two standard deviations above blank values, was $0.5 \mathrm{ng} \mathrm{ml}^{-1}$. For estimation of the accuracy, a cytosolic reference preparation (labelled preparation 311000) was used. The mean $\mathrm{PKC} \delta$ concentration in preparation 311000 was $28.4 \mathrm{ng} \mathrm{ml}^{-1}$, whereas the within-run coefficient of variation (CV) and the between-run $\mathrm{CV}$ were $3.1 \%(n=8)$ and $4.1 \%(n=7)$, respectively.

\section{Statistics}

The Spearman rank correlation was used to compare continuous variables. The Mann-Whitney $U$-test, Kruskal-Wallis test (for continuous/nominal variables) and $\chi^{2}$ test (for nominal data) were used to determine relationships between the various variables. Computations were carried out using SPSS v.11 (SPSS Inc. Headquarters, Chicago, IL, USA). A two-sided $P<0.05$ was considered statistically significant. Protein kinase $\mathrm{C} \delta$ mRNA was related to patient outcome using the Cox regression model. For this analysis, $\mathrm{PKC} \delta$ mRNA level was treated as a continuous variable.

\section{RESULTS}

\section{Protein kinase $\mathbf{C} \boldsymbol{\delta}$ expression in breast carcinomas}

Protein kinase C $\delta$ mRNA was measured by real-time PCR in 208 breast carcinoma samples (see Table 1 for clinical characteristics of the cohort). The median value relative to the housekeeping gene set was 1.97-fold with a range from undetectable to 17.3-fold. Ninety-four representative samples of the 208 analysed by RT PCR were subjected to immunoblotting for $\operatorname{PKC} \delta$ (see also Table 1 for clinical characteristics of this subgroup). Figure 1A illustrates a representative immunoblot of $\mathrm{PKC} \delta$ protein expression, following electrophoresis under reducing conditions. Using a mouse anti$\mathrm{PKC} \delta$ monoclonal antibody (BD Biosciences Pharmingen), two bands were identified, migrating with molecular masses of $\sim 160$ and $78 \mathrm{kDa}$. On the basis of its known molecular mass, the $78 \mathrm{kDa}$ band was regarded as the parent form of PKC $\delta$ (Emoto et al, 1995). To our knowledge, a $160 \mathrm{kDa}$ form of $\mathrm{PKC} \delta$ has not been previously described. Thus, the identity of this band is unknown. The $78 \mathrm{kDa}$ protein was found in 72 out of $94(76.6 \%)$ of the samples. Concentrations ranged from undetectable to 1.97 arbitrary units, the median value being 0.072 arbitrary units. On

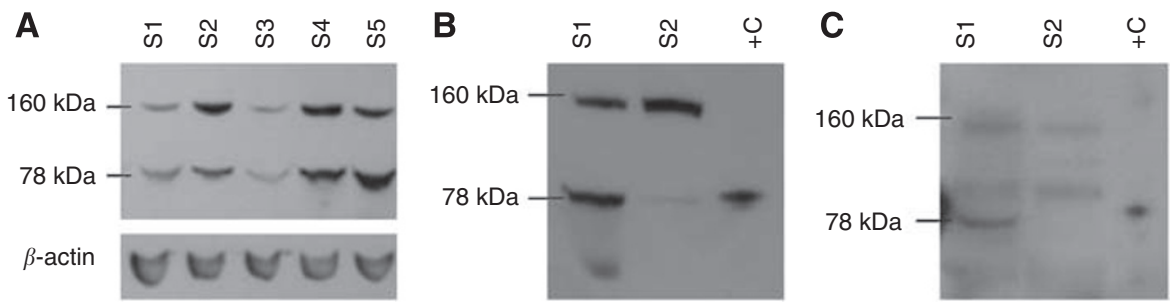

Figure I (A) Representative immunoblot of PKC $\delta$ expression in five primary breast carcinoma samples (SI - S5). Loading control, $\beta$-actin. (B and C) Confirmation of antibody specificity. Protein kinase $\mathrm{C} \delta$ expression was examined in two primary breast carcinoma samples SI and S2 using the mouse antiPKC $\delta$ monoclonal antibody (BD Biosciences) (B) and the rabbit anti-PKCD3 polyclonal antibody (V35) (C). The same carcinoma samples were used in (B) and $(\mathbf{C})$. Positive control, human recombinant $\mathrm{PKC} \delta$ protein $(+\mathrm{C})$. 
the other hand, the $160 \mathrm{kDa}$ protein was detected in 86 out of 94 $(91.5 \%)$ of the samples with concentrations ranging from 0 to 5.15 arbitrary units and a median value of 0.205 arbitrary units.

As a $160 \mathrm{kDa}$ form of PKC $\delta$ had not previously been described, we decided to check its reactivity with a second antibody against $\mathrm{PKC} \delta$. Using a rabbit polyclonal antibody directed against peptide PKCD3, encompassing amino acids $314-329$ of PKC $\delta$ (for details, see Materials and Methods), the $160 \mathrm{kDa}$ band was also detected (Figure $1 \mathrm{~B}$ and $\mathrm{C}$ ), suggesting that this band may be either a new form of $\mathrm{PKC} \delta, \operatorname{PKC} \delta$ complexed to an unknown protein or a protein closely related to $\mathrm{PKC} \delta$. To check the possibility that the $160 \mathrm{kDa}$ band might be a dimer of the parental form of $\mathrm{PKC} \delta$, we increased the concentration of the reducing agent, that is $\beta$ mercaptoethanol, in the loading buffer from 5 to $20 \%$. The pattern of expression for both the $78 \mathrm{kDa}$ parent form and the $160 \mathrm{kDa}$ forms was not altered, suggesting that the $160 \mathrm{kDa}$ protein is unlikely to be a dimer.

Using the Spearman rank correlation test (Figure 2A), a weak but significant correlation was found between the $78 \mathrm{kDa}$ parent form of $\mathrm{PKC} \delta$ and the $160 \mathrm{kDa}$ protein in the carcinomas $\left(r=0.302, r^{2}=0.081, P=0.003, n=94\right)$. Of the 94 samples investigated, $70(74.5 \%)$ were positive for both proteins, whereas six $(6.4 \%)$ were negative for both forms. Two samples $(2.1 \%)$ expressed the $78 \mathrm{kDa}$ form in the absence of the $160 \mathrm{kDa}$ form. Sixteen of the samples (17\%) expressed the $160 \mathrm{kDa}$ form in the absence of the $78 \mathrm{kDa}$ band.

Extracts from 98 samples of the 208 analysed by RT - PCR were assayed for PKC $\delta$ by ELISA. Using ELISA, the total PKC $\delta$ protein concentration ranged from undetectable to $176.0 \mathrm{ng}$ per $\mathrm{mg}$ protein, with the median value being $10.5 \mathrm{ng}$ per $\mathrm{mg}$ protein. A significant but weak correlation was found between the levels of PKC $\delta$ as determined by ELISA and both the $78 \mathrm{kDa}$ form of PKC $\delta$ and the $160 \mathrm{kDa}$ protein determined by immunoblotting (for the $78 \mathrm{kDa}$ form, $r=0.444, r^{2}=0.187, P<0.005, n=91$ and for the $160 \mathrm{kDa}$ form, $r=0.237, r^{2}=0.046, P=0.023, n=91$; Figure $2 \mathrm{~B}$ and $\mathrm{C}$ )

As shown in Figure 2D and E, a significant but weak correlation was found between PKC $\delta$ mRNA expression and both the $78 \mathrm{kDa}$ PKC $\delta$ protein and the $160 \mathrm{kDa}$ band (for the $78 \mathrm{kDa}$ form, $r=0.351, r^{2}=0.114, P=0.001, n=94$ and for the $160 \mathrm{kDa}$ band, $\left.r=0.216, r^{2}=0.036, P=0.037, n=94\right)$. Protein kinase $\mathrm{C} \delta$ mRNA expression also correlated with $\mathrm{PKC} \delta$ protein, as determined by ELISA $\left(r=0.350, r^{2}=0.113, P<0.005, n=98\right.$; Figure $\left.2 \mathrm{~F}\right)$.

\section{Relationship between PKC $\delta$ expression and both tumour characteristics and patient outcome}

Protein kinase $\mathrm{C} \delta$ mRNA and protein levels were related to established prognostic factors for breast cancer, that is tumour size, presence or absence of axillary node metastasis, tumour grade, histology type, ER status and patient age at time of diagnosis (Table 2). No significant correlation was found between PKC $\delta$ expression and tumour size, and the presence or absence of axillary node metastasis or histology type. Levels of PKC $\delta$ mRNA, however, were significantly higher in ER-positive tumours compared with ER-negative tumours (Mann-Whitney $U$-test: $P=0.007, n=202$; Figure $3 \mathrm{~A}$ ) and in patients older than 50 years at diagnosis than in those younger than 50 years (Mann-Whitney
A

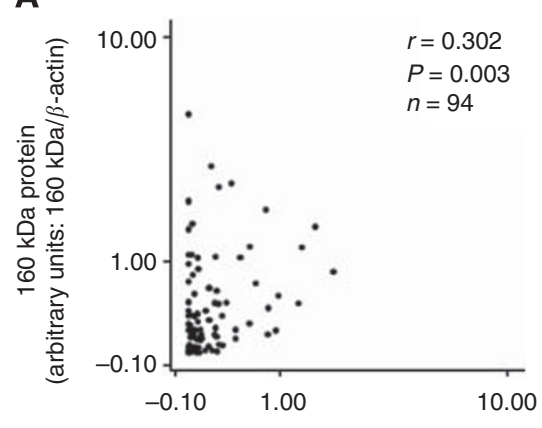

78 kDa PKC $\delta$ protein (arbitrary units: $\mathrm{PKC} \delta / \beta$-actin)

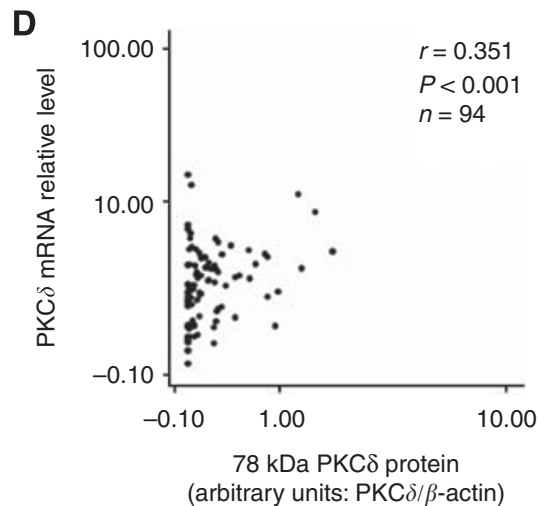

B
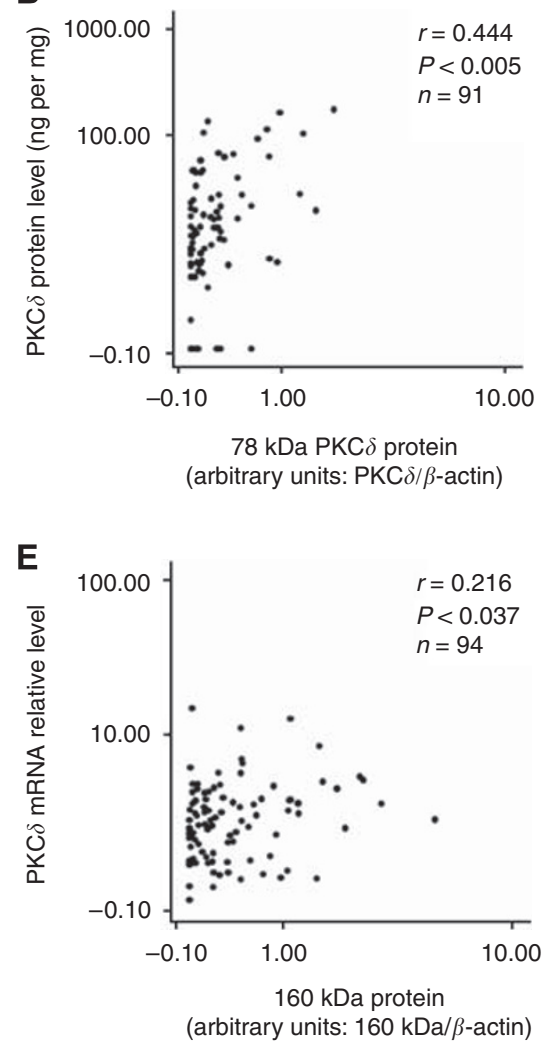

C
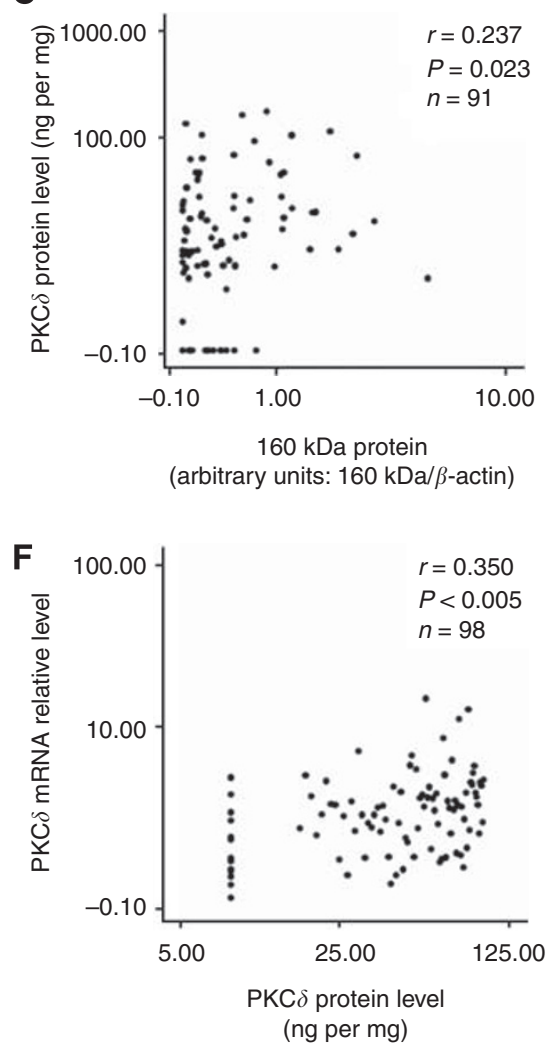

Figure 2 (A) Bivariate scattergram illustrating the relationship between the $78 \mathrm{kDa}$ parent form of PKC $\delta$ and the $160 \mathrm{kDa}$ form. (B and C) Relationship between PKC $\delta$ protein as measured by both ELISA and immunoblot. Bivariate scattergrams illustrating the positive correlations between PKC $\delta$ protein levels as measured by ELISA and (B) the $78 \mathrm{kDa} P K C \delta$ form, (C) the $160 \mathrm{kDa}$ form. (D and E) Relationship between PKC $\delta$ mRNA and PKC $\delta$ protein as measured by real-time PCR and immunoblotting. Bivariate scattergrams illustrating the positive correlations between PKC $\delta$ mRNA and (D) the $78 \mathrm{kDa}$ PKC $\delta$; (E) the $160 \mathrm{kDa}$ form. (F) Bivariate scattergram illustrating the positive correlation between PKC $\delta$ mRNA and total PKC $\delta$ protein as measured by ELISA. Scale on both axes is logarithmic. Analysis performed using the Spearman rank statistical test. 
Table 2 Relationship between PKC $\delta$ expression and characteristics of the breast carcinomas

\begin{tabular}{|c|c|c|c|c|c|c|c|c|c|c|c|}
\hline \multirow{2}{*}{ Tumour characteristics } & \multicolumn{3}{|c|}{ mRNA (PCR) } & \multicolumn{5}{|c|}{ Protein (western blot) } & \multicolumn{3}{|c|}{ Protein (ELISA) } \\
\hline & $n$ & Median & $P$-value & \multicolumn{3}{|c|}{$78 \mathrm{kDa}$ isoform } & \multicolumn{2}{|c|}{$160 \mathrm{kDa}$ isoform } & $n$ & Median & $P$-value \\
\hline \multicolumn{12}{|l|}{ Size $(\mathrm{cm})$} \\
\hline$\leqslant 2$ & 53 & 1.75 & $0.406 *$ & 20 & 0.0288 & $0.139 *$ & 0.2155 & $0.989 *$ & 20 & 10.56 & $0.635 *$ \\
\hline$>2-5$ & 127 & 2.04 & & 62 & 0.0896 & & 0.2051 & & 62 & 12.49 & \\
\hline \multicolumn{12}{|l|}{ Grade } \\
\hline 1 and 2 & 98 & 2.13 & 0.613 & 38 & 0.0315 & 0.016 & 0.2024 & 0.883 & 38 & 7.88 & 0.243 \\
\hline 3 & 100 & 1.8 & & 54 & 0.1003 & & 0.1968 & & 57 & 12.80 & \\
\hline \multicolumn{12}{|l|}{ Nodal status } \\
\hline Negative & 87 & 1.98 & 0.874 & 43 & $0.099 \mid$ & 0.401 & 0.1555 & 0.290 & 41 & 11.68 & 0.580 \\
\hline Positive & 109 & 1.89 & & 48 & 0.0663 & & 0.2981 & & 53 & 9.57 & \\
\hline \multicolumn{12}{|l|}{ Age } \\
\hline$\leqslant 50$ & 65 & 1.97 & 0.029 & 24 & 0.0744 & 0.767 & 0.2335 & 0.900 & 28 & 7.82 & 0.392 \\
\hline$>50$ & 143 & 2.54 & & 70 & 0.0685 & & 0.2 & & 70 & 11.45 & \\
\hline \multicolumn{12}{|l|}{ Histological type } \\
\hline Ductal & 173 & 1.88 & $0.250 *$ & 83 & 0.0742 & $0.889 *$ & 0.2104 & $0.89 \mid *$ & 86 & 9.71 & $0.336 *$ \\
\hline Lobular & 19 & 2.15 & & 6 & 0.1447 & & 0.0917 & & 7 & 20.87 & \\
\hline Ductal and lobular & || & 2.89 & & 3 & 0.062 & & 0.1792 & & 3 & 26.88 & \\
\hline
\end{tabular}

$\mathrm{ER}=$ oestrogen receptor; $\mathrm{PKC}=$ protein kinase $\mathrm{C}$. P-values were determined by either the Mann-Whitney $U$-test or Kruskall-Wallis test* .

$U$-test: $P=0.029, n=208$; Figure $3 \mathrm{~B})$. Levels of the $78 \mathrm{kDa}$ form of $\mathrm{PKC} \delta$, but not the $160 \mathrm{kDa}$ protein, were significantly elevated in high-grade tumours compared with low-grade tumours (MannWhitney $U$-test: $P=0.016, n=92$; Figure $3 \mathrm{C}$ ). Levels of the $160 \mathrm{kDa}$ protein, but not the $78 \mathrm{kDa}$ protein, were significantly elevated in ER-positive tumours compared with ER-negative tumours (Mann-Whitney $U$-test: $P=0.030, n=93$; Figure 3D).

Protein kinase $\mathrm{C} \delta$ mRNA expression was related to both patient disease-free interval and overall survival. Although increasing levels of $\mathrm{PKC} \delta$, treated as a continuous variable, tended to correlate with shorter disease-free interval, this relationship failed to reach statistical significance $(P=0.074)$ (Table 3$)$. However, the increasing expression of $\mathrm{PKC} \delta$ was associated with a significantly shorter overall survival $(P=0.004)$ (Table 3$)$. Other factors associated with shortened survival included tumour size (treated as a continuous variable) $(P=0.015)$, tumour grade (grade $3 v s$ grades 1 and 2 combined) $(P=0.009)$ and the number of lymph nodes with metastasis $(P=0.002)$. Using multivariate analysis, $\mathrm{PKC} \delta$ mRNA predicted overall survival, independent of the traditional prognostic factors (Table 3 ). Protein kinase $\mathrm{C} \delta$ protein levels were not related to patient outcome as the number of samples analysed at the protein level was too low and we did not have enough events (i.e., recurrences or deaths) to provide reliable associations with outcome.

\section{DISCUSSION}

This is one of the most comprehensive studies published to date on $\mathrm{PKC} \delta$ in a large cohort of human breast cancers. Our results show that this gene is variably expressed at both the mRNA and protein levels in breast cancer and that $\mathrm{PKC} \delta$ protein levels in breast cancer specimens, as measured by immunoblotting and ELISA, correlate weakly but significantly with each other and with $\mathrm{PKC} \delta$ mRNA levels. At both mRNA and protein levels, the expression of $\mathrm{PKC} \delta$ was independent of tumour size, lymph node status and histology type. Levels of PKC $\delta$ mRNA were, however, significantly higher in ERpositive compared with ER-negative patients. This finding suggests a possible relationship between $\mathrm{PKC} \delta$ expression and endocrine sensitivity in patients with breast cancer. In this context, it is of interest to note that Martens et al (2005) found that hypermethylation of the PKC $\delta$ gene in ER-positive patients was associated with a favourable response to tamoxifen therapy in advanced breast cancer. Although the effect of hypermethylation on the expression of PKC $\delta$ mRNA was not investigated in that study, gene hypermethylation is generally, but not universally, associated with a decreased expression (Branscombe and Jones, 2007). While this work was in progress, Assender et al (2007) reported that elevated PKC $\delta$ protein, as determined by immunohistochemistry, was associated with endocrine sensitivity in patients with advanced breast cancer.

As only a minority of the patients in this study were treated with hormone monotherapy, it was not possible to investigate the relationship between PKC $\delta$ expression and outcome following such a treatment. Rather, we found that elevated expression of $\operatorname{PKC} \delta$ was associated with poor overall survival. As most of our patients receive systemic adjuvant therapy, it was not possible to conclude whether PKC $\delta$ was prognostic, predictive or both. In any event, our finding of a significant relationship between increased $\mathrm{PKC} \delta$ expression and shortened overall survival is consistent with previous studies from a model system, implicating this kinase in breast cancer metastasis (Kiley et al, 1999).

The association between high expression of PKC $\delta$ and shortened overall survival may appear to be inconsistent with our finding of a positive relationship between the kinase and ER (see above). This is because ER-positive breast cancer patients are generally regarded to have a better prognosis than ER-negative patients (Duffy, 2006). The favourable prognostic impact of ER, however, depends on the adjuvant therapy administered. Thus, in a study on 

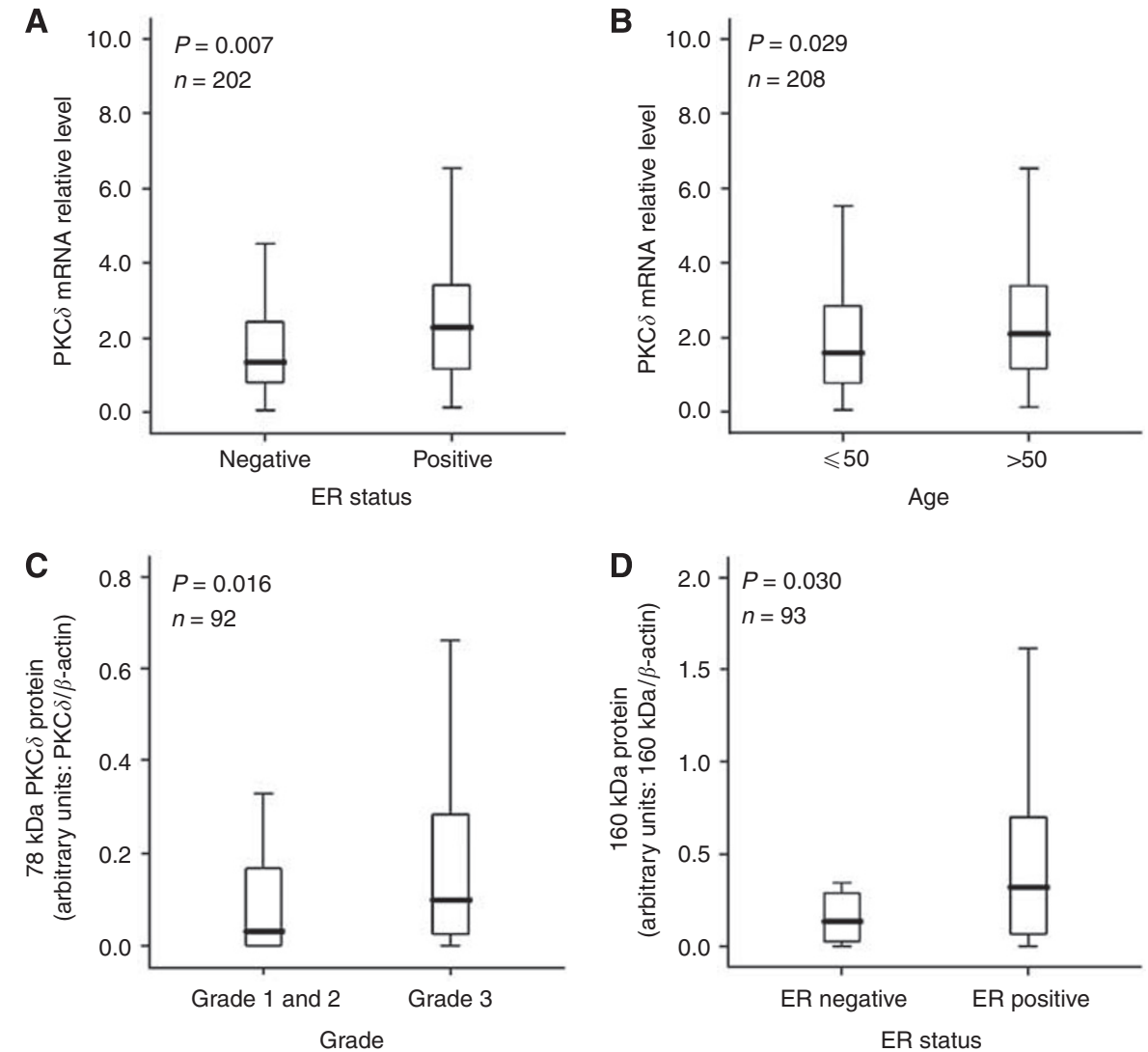

Figure 3 Box plot representing the relationship between $(\mathbf{A})$ PKC $\delta$ mRNA levels and ER status in primary breast carcinomas; (B) PKC $\delta$ mRNA levels and patient age at the time of diagnosis; $(\mathbf{C})$ the $78 \mathrm{kDa} \mathrm{PKC} \delta$ protein form as measured by immunoblot and tumour grade and $(\mathbf{D})$ the $160 \mathrm{kDa}$ form as measured by immunoblot and ER status in primary breast carcinomas. Boxes, 25th and 75th percentiles with the median indicated; bars, 10 th and 90 th percentiles. Analysis was performed using the Mann-Whitney U-test.

Table 3 Relationship between PKC $\delta$ mRNA and both overall survival and disease-free interval in breast cancer

\begin{tabular}{|c|c|c|c|c|}
\hline \multirow[b]{2}{*}{ Factors } & \multirow{2}{*}{$\begin{array}{c}\text { Univariate } \\
\text { analysis } \\
P \text {-value }\end{array}$} & \multicolumn{3}{|c|}{ Multivariate analysis } \\
\hline & & $P$-value & $\mathbf{R R}$ & $95 \% \mathrm{Cl}$ \\
\hline \multicolumn{5}{|l|}{ Overall survival } \\
\hline Tumour size (continuous) & 0.015 & 0.172 & 1.206 & $0.922-1.578$ \\
\hline Nodal category ${ }^{\mathrm{a}}$ & 0.002 & 0.037 & 1.996 & $1.044-3.816$ \\
\hline Tumour grade ( 3 vs I and 2) & 0.009 & 0.079 & 2.796 & $0.887-8.821$ \\
\hline ER status & 0.615 & $N S^{b}$ & & \\
\hline $\mathrm{PKC} \delta$ (continuous) & 0.004 & 0.038 & 1.157 & $1.008-1.328$ \\
\hline \multicolumn{5}{|l|}{ Disease-free interval } \\
\hline Tumour size (continuous) & 0.161 & $N S^{b}$ & & \\
\hline Nodal category ${ }^{\mathrm{a}}$ & 0.001 & 0.021 & 1.871 & $1.098-3.189$ \\
\hline Tumour grade ( 3 vs 1 and 2 ) & 0.010 & 0.074 & 2.370 & $0.919-6.110$ \\
\hline ER status & 0.977 & $N S^{\mathrm{b}}$ & & \\
\hline PKC $\delta$ (continuous) & 0.074 & 0.052 & 1.125 & $0.999-1.268$ \\
\hline
\end{tabular}

$\mathrm{Cl}=$ confidence interval; $\mathrm{PKC}=$ protein kinase $\mathrm{C} ; \mathrm{RR}=$ relative risk. ${ }^{\mathrm{a}}$ Nodal status divided into categories: $0, \quad 1-3$ and $>3$ involved nodes. ${ }^{b} \mathrm{NS}$, not significant $(P>0.05)$.

2562 patients, ER was of prognostic value only in the subgroup treated with adjuvant tamoxifen therapy (Khoshnoud et al, 2008). In our study, only $24 \%$ of the patients received hormone monotherapy, whereas most received combined hormone and chemotherapy. Indeed, ER was not a significant predictor of patient outcome in our group of patients.
Our finding of a significant relationship between $\operatorname{PKC} \delta$ and overall survival, but not between the kinase and disease-free interval, may relate to the fact that almost all our patients received some form of systemic adjuvant therapy. A potential adverse prognostic impact of $\mathrm{PKC} \delta$ could thus be neutralised or partially neutralised by this adjuvant treatment. It should also be added that while the association between $\mathrm{PKC} \delta$ and disease-free interval did not reach statistical significance, there was a trend towards significance, that is the $P$-values were 0.074 and 0.052 using univariate and multivariate analyses, respectively.

Following immunoblotting with two different antibodies against $\mathrm{PKC} \delta$, we identified two main proteins, migrating with molecular masses of 78 and $160 \mathrm{kDa}$. On the basis of its known molecular mass, the $78 \mathrm{kDa}$ band was taken to represent the mature form of $\mathrm{PKC} \delta$. To our knowledge, a $160 \mathrm{kDa}$ form of $\mathrm{PKC} \delta$ has not previously been described. Further work is therefore required to establish whether it is a new form of $\mathrm{PKC} \delta$, a protein related to $\mathrm{PKC} \delta$, a complex of $\mathrm{PKC} \delta$ with an unknown protein or indeed a non-specific band.

The $78 \mathrm{kDa}$ form of PKC $\delta$ was expressed at higher levels in highgrade (that is, grade 3 ) compared with low-grade (that is, grade 1 and 2) tumours. Grade is a well-established prognostic factor for breast cancer with increasing grade generally being associated with poorer outcome (Soerjomataram et al, 2008). The finding of a positive relationship between levels of the $78 \mathrm{kDa}$ form of PKC $\delta$ and grade is consistent with our finding that elevated expression of $\mathrm{PKC} \delta$ mRNA was associated with poor outcome.

As mentioned in the introduction, there is considerable debate at present as to whether $\mathrm{PKC} \delta$ is involved in promoting or inhibiting cancer progression. Our finding here of an 
association between elevated $\mathrm{PKC} \delta$ mRNA expression and poor outcome suggests a role for $\operatorname{PKC} \delta$ in tumour progression, at least in human breast cancer. Further studies, ideally using prospective randomised trials, are required to establish whether $\mathrm{PKC} \delta$ has prognostic or predictive roles in breast cancer.

\section{REFERENCES}

Assender JW, Gee JMW, Lewis I, Ellis O, Robertson JFR, Nicholson RI (2007) Protein kinase C isoform expression as a predictor of disease outcome on endocrine therapy in breast cancer. J Clin Pathol 60: $1216-1221$

Branscombe MT, Jones PA (2007) DNA methylation: the nuts and bolts of repression. J Cell Physiol 213: $384-390$

Duffy MJ (2006) Estrogen receptors: role in breast cancer. Crit Rev Clin Lab Sci 43: $325-347$

Emoto Y, Manome Y, Meinhardt G, Kisaki H, Kharbanda S, Robertson M, Ghayur T, Wong WW, Kamen R, Weichselbaum R, Kufe D (1995) Proteolytic activation of protein kinase $\mathrm{C} \delta$ by ICE-like protease in apoptotic cells. EMBO J 14: 6148-6156

Grebenchtchikov N, Sweep CGJ, Geurts-Moespot A, Piffanelli A, Foekens JA, Benraad TJ (2002) An ELISA avoiding interference by heterophilic antibodies in the measurement of components of the plasminogen activation system in blood. J Immunol Methods 268: 219-231

Grebenschikov N, Geurts-Moespot A, De Witte H, Heuvel J, Leake R, Sweep F, Benraad T (1997) A sensitive and robust assay for urokinase and tissue-type plasminogen activators ( $\mathrm{uPA}$ and $\mathrm{tPA}$ ) and their inhibitor type 1 (PAI-1) in breast tumor cytosols. Int J Biol Markers 12: $6-14$

Griner EM, Kazanietz MG (2007) Protein kinase C and other diacylglycerol effectors in cancer. Nat Rev Cancer 7: $281-294$

Jackson DN, Foster DA (2004) The enigmatic protein kinase C $\delta$ : complex roles in cell proliferation and survival. FASEB J 18: 627-636

\section{ACKNOWLEDGEMENTS}

This study was funded by the European Union 6th Framework Programme (LSHC-CT-2003-504586) and with a grant from the Health Research Board of Ireland (Breast Cancer Metastasis: Biomarkers and Functional Mediators, PRP/2005/35).

Khoshnoud MR, Fornander T, Johansson H, Rutqvist L-R (2008) Long-term pattern of disease recurrence among patients with early-stage breast cancer according to estrogen receptor status and use of adjuvant tamoxifen. Breast Cancer Res Treat 107: 71-78

Kiley SC, Clark KJ, Goodnough M, Welch DR, Jaken S (1999) Protein kinase $\mathrm{C}$ delta involvement in mammary tumor cell metastasis. Cancer Res 59: $3230-3238$

Martens JWM, Nimmrich I, Koenig T, Look MP, Harbeck N, Model F, Kluth A, Bolt-de Vries J, Sieuwerts AM, Portengen H, Meijer-Van Gelder ME, Piepenbrock C, Olek A, Höfler H, Kiechle M, Klijn JGM, Schmitt M, Maier S, Foekens JA (2005) Association of DNA methylation of phosphoserine aminotransferase with response to endocrine therapy in patients with recurrent breast cancer. Cancer Res 65: 4101-4107

Nabha SM, Glaros S, Hong M, Lykkesfeldt AE, Schiff R, Osborne K, Reddy $\mathrm{KB}$ (2005) Upregulation of PKC-delta contributes to antiestrogen resistance in mammary tumor cells. Oncogene 24: 3166-3176

Sieuwerts AM, Meijer-van Gelder ME, Timmermans M, Trapman AMAC Rodriguez Garcia R, Arnold M, Goedheer AJW, Portengen H, Klijn JGM, Foekens JA (2005) How ADAM-9 and ADAM-11 differentially from estrogen receptor predict response to tamoxifen treatment in patients with recurrent breast cancer: a retrospective study. Clin Cancer Res 11: $7311-7321$

Soerjomataram I, Louwman MWJ, Ribot JG, Roukema JA, Coebergh JWW (2008) An overview of prognostic factors for long-term survivors of breast cancer. Breast Cancer Res Treat 107: 309-330 